\title{
Temporal and spatial changes in phyllosphere microbiome of acacia trees growing in arid environments
}

\author{
Ashraf Al-Ashhab ( $\square$ ashraf@adssc.org ) \\ Dead Sea and Arava Science Center https://orcid.org/0000-0002-3716-2279

\section{Shiri Meshner} \\ Dead Sea and Arava Science Center
}

\section{Rivka Alexander-Shani}

Dead Sea and Arava Science Center

\section{Hana Dimerets}

Dead Sea and Arava Science Center

\section{Michael Brandwein}

Dead Sea and Arava Science Center

\section{Yael Bar-Lavan}

Dead Sea and Arava Science Center

\section{Gidon Winters}

Dead Sea and Arava Science Center

\section{Research article}

Keywords: Acacia raddiana, Acacia tortilis, Phyllosphere, Desert plants, Microbiome, Endophytes, Epiphytes

Posted Date: January 11th, 2021

DOI: https://doi.org/10.21203/rs.3.rs-15477/v2

License: (c) (i) This work is licensed under a Creative Commons Attribution 4.0 International License. Read Full License

Version of Record: A version of this preprint was published at Frontiers in Microbiology on July 12th, 2021. See the published version at https://doi.org/10.3389/fmicb.2021.656269. 


\section{Abstract}

Background: The evolutionary relationships and interactions between plants and their microbiomes are of high importance to the survival of plants in extreme conditions. Changes in the plant's microbiome can affect plant development, growth and health. Along the arid Arava, southern Israel, acacia trees (Acacia raddiana and Acacia tortilis) are considered keystone species. In this study, we investigated the ecological effects of plant species, microclimate (different areas within the tree canopy) and seasonality on the epiphytic and endophytic microbiomes associated with these two tree species. One hundred and thirty nine leaf samples were collected throughout the year and their microbial communities were assessed using 16S rDNA gene amplified with five different primers (targeting different gene regions) and sequenced (150 bp paired-end) on an Illumina MiSeq sequencing platform.

Results: Epiphytic bacterial diversity estimates (Shannon-Wiener, Cha01, Simpson and observed number of OTUs), were found to be nearly double compared to endophyte counterparts, in addition epi- and endophyte communities were significantly different from each other. Interestingly, the epiphytic bacterial diversity was similar in the two acacia species but the canopy sides and sample months exhibited different diversity, while the endophytic bacterial communities were different in the two acacia species but similar throughout the year. Abiotic factors, such as air temperature and precipitation, were shown to significantly affect both epi- and endophytes communities. Bacterial community compositions showed that Firmicutes dominate Acacia raddiana and Proteobacteria dominate Acacia tortilis, these bacterial communities only consisted of a small number of bacterial families mainly Bacillaceae and Comamonadaceae in the endophyte for $A$. raddiana and $A$. tortilis, respectively, and Geodematophilaceae and Micrococcaceae for epiphyte bacterial communities. Interestingly, about $60 \%$ of the obtained bacterial classification were unclassified below family level.

Conclusions: These results shed light on the unique desert phyllosphere microbiome highlighting the importance of multiple genotypic and abiotic factors in shaping the epiphytic and endophytic microbial communities. This study also shows that only a few bacterial families dominate both epi- and endophytes, highlighting the importance of climate change (precipitation, air temperature and humidity) in affecting arid land ecosystems where acacia trees are considered keystone species.

\section{Background}

The above-ground surfaces of plants (the phyllosphere) harbor a diverse variety of microorganisms, including bacteria [1]. The microbiome of the plant phyllosphere has been shown to play an important role in the adaptation of the plant host to different environments such as tolerance to heat, cold, drought and salinity [2-6]. Several studies have suggested that the eco-physiological adaptation of desert plants to their harsh habitat is at least partially via microbial functional diversity $[3,7]$. While the exact correlation of phyllosphere microbial communities and these unique adaptations is yet to be clarified, a growing body of literature indicates that each plant species provides a unique microenvironment that is suitable to its bacterial communities. Plant phyllosphere microbes were found to differ among different 
habitat and climate conditions when compared among arid, semi-arid and temperate habitats. For instance, Martirosyan et al. (2016) investigated the adaptation of three Negev desert plant species and found gram-negative Bacteroidetes to dominate the leaves of Hammada scoparia while practically absent in other desert plant species [8]. These microbes were also found to correlate with high temperature, droughts and UV radiation $[9,10]$, regardless of their geographical location [11]. In this context, desert phyllosphere microbiome were shown to mediate plant growth and the metabolism of some nutrients by fixing nitrogen from atmospheric sources [12], utilizing phosphorus through solubilizing enzymes $[13,14]$ and producing siderophores to bind iron $[15,16]$, and even increasing plant resistance against pathogens such as botrytis fungal infection (i.e., blight disease) $[17,18]$.

Alongside the effects of seasonality $[7,19,20]$ and canopy structure [21] on plant phyllosphere microbiome, other studies have shown that abiotic (climate-related) and biotic (plant genotype) factors also play an important role in structuring the phyllosphere microbial communities [22]. In fact, epiphytic (outside the leaves of plants) and endophytic (inside the leaves of plants) microbial communities were shown to be different in composition: epiphytic bacterial communities were richer and more abundant compared with the endophytic bacterial communities; moreover, abiotic factors were shown to have different effects on epiphytic and endophytic bacterial communities. Season was the major driver of community composition of epiphytes while wind speed, rainfall, and temperature were the major drivers shaping endophytic composition [23].

These complex interactions between plant microbiome (both epiphytic and endophytic) and different biotic and abiotic conditions within arid ecosystems is of particular interest considering the current scenarios of climate change and desertification [24]. Additionally, studies on microbiomes in arid plants could shed new light on important key microbial groups that might be of potential use in arid agricultural practices, biotechnology and plant adaptation strategies to climate change [25].

In this study, we investigated the epiphytic and endophytic microbiome associated with the phyllosphere (leaves) of Acacia raddiana (Savi) and Acacia tortilis (Forssk) (Fig. 1B) in the Negev Desert (Fig. 1A). These two tree species grow in some of the hottest and driest places on Earth, such as the arid Arava Valley along the Syrian-African rift system (Dead Sea Transform) in southern Israel and Jordan. In these arid habitats, Acacia raddiana and Acacia tortilis are the most abundant or only tree species present [26]; they are mostly found growing in the channels of ephemeral river beds [27]. Both Acacia raddiana and Acacia tortilis are considered keystone species that support the majority of the biodiversity surrounding them, and locally improve soil conditions for other plant species [27-31]. We hypothesized that variations in the bacterial communities of phyllosphere would be associated not only with the host species $(A$. raddiana and $A$. tortilis), but also with sampling season (temporal variations) and tree microclimate (leaves growing on the north or south side of tree canopy are shaded or exposed to direct sun radiation; spatial variations) (Fig.1D).

\section{Results}


A total of 139 acacia leaf samples ( 2 tree species $\times 2$ replicate trees $\times$ ( 3 canopy locations for epiphytes +1 south canopy for endophytes) $\times 9$ months) were collected for both epiphytic and endophytic microbial communities (Table S1; notice a total of 7 samples were lost during sample processing before sequencing) and sequenced for their 16S rRNA genes using five different primer sets for amplifying different variable regions within the 16S rRNA gene (Table S2). The average sequence number per each primer set varied significantly for the different regions of amplification (Table S2). Results showed the third primer set (F649 and R889) was able to obtain the highest number of raw sequences with an average raw sequence number of $38,683 \pm 18,723$ and thus we based all further analysis on the F649R889 primer set. This primer set retained its rank amongst all other primer sets even after the quality control (QC) procedure, with 15,424 $\pm 13,784$ high quality sequences. This quality control step included removal of low quality and incomplete sequences, removal of chimeric sequences and discarding of chloroplasts, mitochondrial and unclassified bacterial sequences (Table S2).

\subsection{Acacia bacterial community - composition of epiphytic compared to endophytic assemblages}

To compare epi- and endophytic bacterial community structure, leaf samples were collected only at the south ("S") canopy side of the acacia trees (Table S1). Diversity estimates, including observed number of OTUs, Chao1, Simpson index and Shannon-Wiener, were calculated for both $A$. raddiana and $A$. tortilis and recorded in Table 1. Epiphytic bacterial diversity was higher when compared to endophytic bacterial communities (Table 1) indicating a different bacterial structure. To compare the diversities of epiphytic and endophytic bacterial communities extracted from leaf samples, acacia samples from south-facing canopies were analyzed and plotted using non-metric multidimensional scaling (NMDS), based on the Bray-Curtis distance matrix (Fig. 2). Using analysis of similarity test (ANOSIM), two separate clusters of epiphytic and endophytic bacterial communities were found to be significantly different $(p=0.001$; Fig. $2 A$ ). While the epiphytic bacterial communities from both acacia species (A. raddiana and $A$. tortilis) did not demonstrate separate clusters ( $p$-value $=0.474$, Fig. $2 A$ ), the endophytic bacterial communities showed to be significantly different for both acacia species ( $p$-value=0.004, Fig. 2B). To illustrate these differences, we plotted the bacterial phylum with more than $5 \%$ of the total community composition (Fig. 3) and performed Tukey's test of significance on the log-transformed abundances to normalize the variance. Results showed a higher median abundance of Actinobacteria in A. raddiana and A. tortilis, when comparing epiphytic to endophytic bacterial communities. However, these differences were only significant for $A$. tortilis ( $45.2 \pm 17.7 \%$ and $9.0 \pm 5.9 \%$, p-value $<0.05)$ and not for $A$. raddiana $(44.5 \pm$ $19.2 \%$ and $5.7 \pm 10.0 \%$, p-value $>0.05$ ) (Fig. 3). Similarly, Cyanobacteria median abundance was higher in epiphytic compared to endophytic bacterial communities, and was significant for $A$. tortilis $(2.6 \pm 5.8 \%$ and $0.4 \pm 0.4 \%$, p-value < 0.05 ) and not for $A$. raddiana ( $2.5 \pm 5.2 \%$ and $0.5 \pm 0.4 \%$, p-value $>0.05$ ) (Fig. 3 ). On the other hand, the abundance of both Firmicutes and Proteobacteria were lower in epi-compared to endophytic bacterial communities and was significantly different among the two acacia species ( $\mathrm{p}$-value $<0.05$ ). The median abundance of Firmicutes in $A$. raddiana epiphytes was $21.4 \pm 10.1 \%$ compared to $76.3 \pm 32.4$ in endophytes, and in A. tortilis was $15.8 \pm 12.2$ and $25.1 \pm 27.6$, respectively (Fig. 3 ). The median abundance of Proteobacteria in epiphytes and endophytes of $A$. raddiana was $13.5 \pm 12.1$ and $19.1 \pm 21.3$, and of $A$. tortilis was $13.2 \pm 8.4$ and $65.5 \pm 26.2$, respectively (Fig. 3 ). 


\subsection{Acacia temporal and spatial (canopy side) and abiotic variation of phyllosphere bacterial}

communities

\section{- Temporal and spatial variation}

To test the temporal effect on bacterial communities, acacia leaf samples from different canopy sites (for epiphytes) and at south canopy sites at different sampling times (endophytes) (Months; Table S1) were analyzed and plotted using NMDS based on Bray-Curtis distance matrix. A gradient color scale for different months was set to correspond to the different seasons and maximum air temperature (the blue gradient corresponds to the cold, early months of the year, green to yellow represent the spring and early summer months, and red represents the hot summer months) (Fig. 4A). Epiphytic bacterial communities from the north-facing canopy showed to cluster in a closer aggregate compared to the spatial arrangement of the bacterial communities sampled from the central and south-facing canopy. When further PERMANOVA (adonis2) analysis was performed, the result showed the epiphyte microbial community to significantly differ between canopy placement across time ( $p$-value $=0.004$, Table 2 ). Similarly, epiphytic and endophytic bacterial communities were plotted across different months for only the south-facing canopy (Fig. 4B) and tested across time using PERMANOVA analysis; both epi-and endophytes were significantly different across sampling months ( $p$-value $=0.015$, Table 3 ). Nonetheless when we tested epiphyte and endophyte microbial community significance separately across sampling month alone, only epiphytes showed to be significant $(p$-value $=0.001)$ compared to endophytes $(p$ value $=0.161)$.

\section{- Abiotic variation}

To test whether other abiotic factors affect the microbial communities, canonical correspondence analysis (CCA) [32] was performed for the epiphytic (Fig. 5A) and endophytic (Fig. 5B) bacterial communities of $A$. raddiana and $A$. tortilis. Only those abiotic factors with significant values ( $p$-value $\leq$ 0.05 ) were plotted. Results show that air temperature, vapour-pressure deficit (VPD), humidity and precipitation had a significant effect on the epiphytic bacterial communities and were able to explain $30.4 \%$ and $18.6 \%$ (CCA axis 1 and 2; respectively) of total bacterial community variations (Fig. 5A), while temperature and precipitation had a significant effect on the endophytic bacterial communities explaining $16.6 \%$ and $7.3 \%$ of the variations (CCA axis 1 and 2 ; respectively) (Fig. 5B).

\section{- Bacterial family abundances}

To test for the major changes in bacterial family abundances, a heatmap was made to show epi- and endophytic bacterial diversity at the family level (Fig. 6). Results show that only a few bacterial OTUs were differentially abundant comparing epi- and endophytes, or when comparing within the endophytic communities found in $A$. raddiana and $A$. tortilis. Epiphytic bacterial communities were mainly dominated by Geodermatophilaceae, Micrococcaceae, Comamonadaceae and Bacillaceae bacterial families, while endophytic bacterial communities were only dominated by alternating abundances of Bacillaceae, Comamonadaceae and Moraxellaceae families. In the endophytic bacterial community, these changes in 
abundance correlated with the months of the year; the blue-dark green gradient (indicating the colder month of the year; Fig. 6) exhibited a higher abundance of Bacillaceae than Comamonadaceae family, which was more abundant in hotter months of the year (May-November; Fig. 6). Moreover, endophytic $A$. raddiana showed to have a higher abundance of Bacillaceae than Comamonadaceae family, which was more abundant in $A$. tortilis.

\section{Discussion}

To improve our understanding of the microbial structure of the phyllosphere microbiome of plants growing in extreme arid environments, we applied a high temporal and spatial resolution sampling scheme in two desert keystone trees (Acacia raddiana and Acacia tortilis). We investigated both the epiphytic and endophytic bacterial communities to understand the: (i) intra- and inter-individual spatial variation of the microbial community within a tree - the spatial variation within the same tree caused by sun exposure (only for epiphytic microbial communities), and the variation between neighboring trees of the same species sampled at the same time and site (ii) host species variation (variation of the microbial community caused by the host (tree) species (i.e., Acacia raddiana compared with neighboring Acacia tortilis), (iii) temporal variation of the microbial community within the same tree species, canopy side and individual trees sampled during different seasons.

Our results demonstrate that the epiphytic bacterial communities were more sensitive to changes in environmental abiotic conditions, compared with the endophytic bacterial communities that were more stable between different environmental conditions (e.g., seasons) but varied among host tree species. Surprisingly, up to $60 \%$ of the total bacterial communities (the combined epiphytic and endophytic microbiome populations) were unclassified below family level, highlighting the uniqueness of the microbiome associated with acacia trees in the arid environment of the Arava. When actinobacterial differences were compared in tree grove, shrub, meadow, desert, and farm soil ecosystems, the majority of unclassified actinobacterial sequences were found in desert ecosystems, accounting for about $50 \%$ of total actinobacteria phylum [33]. Similar results from a study of desert soil in Pakistan indicate that a bulk portion of the OTUs were assigned to unclassified taxa [34].

In terms of the overall observed number of OTUs, Chao1, Simpson's and Shannon-Wiener diversity indices, the diversity of the epiphytic bacterial community was shown to double that of its endophytic bacterial community counterpart (Table 1). While the average number of classified bacteria sequences for epiphytes was slightly higher $(16,752)$ compared to endophytic $(14,857)$ bacterial communities, the sequence number in each sample had no effect on the obtained diversity indices (Fig. S2). The higher abundance and richer microbial communities in epiphytes compared to endophytes was also observed in young and mature leaves of Origanum vulgare, where the total number of colony-forming units (CFU) of epiphytic bacterial communities $(5.0 \pm 0.2)$ was more than double the CFU of the associated endophytic communities (1.8 \pm 0.1$)$ [35]. However, our results contradict previous work on microbiomes associated with Arabidopsis thaliana where epiphytic bacterial diversity indexes were found to be lower than those measured for the associated endophytic bacterial communities [36]. Like the work shown here, a recent 
study on the epiphytic and endophytic fungal diversity in leaves of olive trees (Olea europaea) growing in Mediterranean environments also showed that the epiphytic fungal communities had higher diversity indices compared to the endophytic diversity estimates [23]. The fact that our epiphytic OTU diversity was higher than the endophytic diversity is particularly surprising, considering previous work by Thapa et al. (2018) that suggested that the conditions inside the plant might be more favorable compared to the hostile conditions on the outside [37]. This might explain findings from other studies where diversity was higher for endophytic microbiomes. In our case, however, both $A$. raddiana and $A$. tortilis had a lower endophytic bacterial diversity compared to epiphytic bacterial diversity throughout the sampling regime (Table S4); the lower diversity of endophytic microbial communities compared to epiphytic communities may be a result of plant stress and physiological conditions regulated by stomatal opening [38, 39]. In fact, Chao 1 richness in epiphytic microbial communities in $A$. raddiana and $A$. tortilis was higher in January, March and November compared to summer months and corresponded to plant water vapour pressure deficit (VPD) stressing the importance of the physiological state of the plant in shaping endophytic bacterial communities (Fig. S3, Table S4). These plant responses were shown to reduce entry of epiphytes to the endosphere, thus affecting plant microbiome colonization [35, 40,41].

Our results demonstrate that the epiphytic and endophytic bacterial communities are significantly unique (Fig. 2A, and Fig. 6). We also found that the endophytic (but not epiphytic) bacteria communities differed between the two acacia species (Figs. 2A, 2B and Fig. 6), with host specific endophytic communities. In fact, many reports have indicated that the composition and abundance of endophytes in plants is synergistically determined by plant genotype and environmental factors [42]. Plant tissue characteristics highly affect microbial abundance, thus endophyte enrichment varies widely in different tissues within a plant [43]. The significant effect of genotype on composition of endophytic microbial communities has been documented [44-46], and it is more severely affected by genotypic factors than by abiotic factors $[5,6,22]$.

Like other findings indicating the changes in bacterial communities in the phyllosphere due to different environmental and biotic factors $[40,41]$, our results show that seasonality (temperature and month) is the major driver of community composition in epiphytic bacteria (Fig. 4A and Fig. 5A). Humidity, temperature, precipitation and VPD were shown to have a strong effect explaining $30.4 \%$ and $18.6 \%$ in CCA axis 1 and 2 respectively, accounting for the total variance in microbial community composition (Fig. $5 A)$. In the endophytic bacterial communities, temperature and precipitation explained $14.6 \%$ and $7.3 \%$ of the total microbial community (Fig. 5B). It was suggested that abiotic regulatory factors affect the physicochemical properties of the leaf; in addition these abiotic factors can affect external biotic factors (e.g. insects and pathogens) which in turn affect the plant's immunity and biology and therefore affect plant-associated microbiome [47]. Nonetheless, plants undergo remarkable physiological changes in relation to abiotic factors; such changes can affect the availability of nutrients, water and a wide range of secondary metabolites on the leaf surface and therefore significantly affect the epiphytic microbial communities [47]. Moreover, the effect of microclimate (i.e., the spatial variation caused by the different canopy sides) on the epiphytic bacterial diversity (Table 1, Table 2) and community composition (Fig. 4A) was shown to be significant. However, we only tested the effect of exposure to sun on epiphytes. A recent 
study investigated the endophytes of roots and leaves of Oxyria digyna showing the strong impact of tissue type on the endophytic bacterial community structure [48]. Assessing the different canopy sides showed that exposure to the sun significantly affects the physiological state of leaves [49] and forms distinct epiphytic microbial communities; therefore, the effect of canopy side on the endophytic phyllosphere microbial communities needs further investigation.

We also showed that the bacterial community compositions found in this study differ from epiphytic or endophytic microbiome found in tropical regions, and significantly correlate with abiotic condition and temporal variation (Table 3). Our microbial community compositions also differ compared to those found in phyllosphere of subtropical and temperate regions, which are mostly dominated by Alphaproteobacteria (72\%) [50], Bacteroidetes (8\%) and Acidobacteria (17\%) [51], whereas ours were dominated by Firmicutes, Proteobacteria (mainly Betaproteobacteria (Fig. 6)) and Actinobacteria (Fig. 3). The major differences between epiphytic and endophytic bacterial communities were due to the differential abundance of four major unclassified OTUs belonging the bacterial families of Bacillaceae (Firmicutes phylum) and Comamonadaceae (Betaproteobacteria phylum) for the endophyte of $A$. raddiana and $A$. tortilis, respectively (Fig. 6). Other unclassified OTUs belonging to the bacterial families of Geodematophilaceae and Micrococcaceae (both belonging to Actinobacteria phylum) were found in the epiphyte bacterial communities (Fig. 6). These bacterial families were also found in other extremecondition studies that investigated the metagenomic signatures of the phyllosphere of Tamarix $[11,52$, 53] and other desert shrubs [8], highlighting the relationships between these bacterial communities and their importance in the adaptation of desert plants to arid environments. However, the exact link between

these different bacterial groups and their functional diversity is still to be investigated; such studies could shed light on the specific metabolites and enzymes that these adaptive bacterial groups exhibit in arid environments. With the growing interest in manipulating and inoculating food crops with particular microbial communities to extend shelf life and improve plant resilience and product taste, the longcoevolved microbiome of desert plants might have biotechnological potential. Desert plant microbiome may enhance the resilience of crop plants during ongoing processes of desertification and soil salinization expected to affect vast regions of the world in coming decades.

\section{Conclusions}

The evolutionary relationships and interactions between plants and their microbiome are important for their adaptation to extreme conditions. In this study, we explored the spatiotemporal relationships between naturally occurring desert plants and their microbiome. While changes in the plant microbiome can affect plant development, growth and health, we presented the effects of plant physiological conditions, temporal changes, canopy structure, abiotic parameters, and plant genotype on both epi- and endophytic bacterial communities of desert plant phyllosphere. Moreover, we showed how the desert plant phyllosphere is inhabited by distinct microbial communities compared to temperate and humid regions, stressing that a large portion of these microbial communities are not classified below family level. Our results shed light on the specific bacterial families and diversity patterns in relation to desert phyllosphere epi- and endophytes associated with extreme environmental conditions. The agritech 
potential of these unique microbial communities calls for more research on the functionality of these epiphytic and endophytic microbial communities.

\section{Materials And Methods}

\subsection{Study area and sampling scheme}

This study was conducted in the Arava Valley, a hyper-arid region along the Dead Sea Transform in southern Israel and Jordan. The elevation of the area ranges from $230 \mathrm{~m}$ above sea level to $419 \mathrm{~m}$ below sea level (Fig. 1A). The climate in the Arava Valley is hot and dry: 30-year average minimum, mean, and maximum air temperature of the hottest month was $26.2^{\circ} \mathrm{C}, 33.2^{\circ} \mathrm{C}$, and $40.2^{\circ} \mathrm{C}$, respectively; average minimum, mean, and maximum air temperature of the coolest month were recorded as $9.1^{\circ} \mathrm{C}, 14.4^{\circ} \mathrm{C}$, and $19.6{ }^{\circ} \mathrm{C}$, respectively. Annual precipitation ranges between $20-70 \mathrm{~mm} /$ year, and is restricted to the period between October and May [31] with large temporal (year-to-year) and spatial variations [54]. The combination of the very high air temperatures and the very low relative humidity values of $6 \%$ can cause summer midday vapour pressure deficit (VPD) to reach $9 \mathrm{kPa}$ [31]. Vegetation in the region is usually confined to wadis (ephemeral river beds [55]), where the main water supply comes from underground aquifers $[56,57]$ and winter flash floods [58]. Multiple individual $A$. raddiana and $A$. tortilis trees are scattered throughout Wadi Shizaf (Fig. 1A), but never form a continuous canopy. To investigate the effect of different canopy sides on the phyllosphere microbiome, leaf samples were collected from three different canopy sides (north, center and south; Fig. 1D).

Wadi Shizaf is a dry sandy streambed at the northern edge of the Arava Valley, Israel (Fig. $1 \mathrm{~A} ; 30^{\circ} 44^{\prime} \mathrm{N}$, $35^{\circ} 14^{\prime} \mathrm{E}$; elevation $-137 \mathrm{~m}$ ). Meteorological data (air temperature and humidity logged every three hours) for this site were obtained from the Israeli Meteorological Service (IMS) for station 340528 at Hatzeva, located only $7 \mathrm{~km}$ north of Wadi Shizaf (Fig. S1).

To sample bacteria from acacia trees in Wadi Shizaf, two neighboring $A$. tortilis trees ( $>20 \mathrm{~m}$ away from each other) (T023 and T300) and two neighboring $A$. raddiana trees (R284 and R286), were sampled monthly between January and December 2015 on their north, south and central canopy sides (Fig. 1D and Table S1). This sampling scheme was chosen to enable us to investigate the effect of two different host (tree) species, in addition to the variation caused by the sampling season and the microclimate effect (different canopy sites - north, central, and south-facing sides of tree) on the phyllosphere microbiome.

During all sampling months, samples were collected from trees using sterile gloves (changed between each sample). Leaves (20-25 g fresh weight) were collected monthly (see Table S1 for exact dates) and inserted into $15 \mathrm{ml}$ sterile tubes placed on ice. Upon reaching the laboratory (within <2 hrs) samples were moved to freezers $\left(-20^{\circ} \mathrm{C}\right)$ where they were kept until subjected to DNA extraction. 


\subsection{DNA extraction}

All DNA extractions were performed using the MoBio 96-well plate PowerSoil DNA Isolation Kits (MO BIO Laboratories, California, USA). For epiphyte (outside of plant leaves) microbial community extractions, $0.15 \mathrm{~g}$ (FW) of leaves were weighed and placed in $1.5 \mathrm{ml}$ Eppendorf tubes filled with $500 \mu \mathrm{l}$ MoBio Powerbead Solution and sonicated (DG-1300 Ultrasonic cleaner, MRC LAB, Israel) for 5 min. Then the solution was transferred to the Powerbead Tubes and the remaining steps for DNA extraction were carried out following the manufacturer's protocol. For the extraction of endophytic (inside plant leaves) microbial communities, leaves were washed using $1 \mathrm{ml}$ of DNA/RNA free water three times to eliminate the epiphyte microbiome fraction. The washed leaves were then cut into small pieces using a sterile scalpel and placed into the MoBio 96-well Powerbead plate for DNA extraction following the manufacturer's protocol. All steps of DNA extraction were carried out in a sterile UV-hood (DNA/RNA UV-cleaner box, UVTS-AR bioSan, Ornat, Israel) to reduce external contaminations. In every DNA extraction, using a 96-well plate, DNA extraction negative controls were added by placing $200 \mu$ l of RNase free water (Sigma Aldrich, Israel). All samples were placed randomly in the DNA extraction plate to exclude any bias.

\subsection{PCR, library preparation and Illumina sequencing}

In order to obtain a better phylogenetic resolution and diversity estimate, a multiplex PCR using five different sets of the 16S rDNA genes was applied to cover about 1000bp of the 16S rRNA gene (Table S2).

First PCR (PCR-I) reactions were performed in triplicates, where each PCR-I reaction (total $25 \mu \mathrm{l}$ ) contained; $12.5 \mu$ l of KAPA HiFi HotStart ReadyMix (biosystems, Israel); $0.4 \mu \mathrm{l}$ of equal v/v mixed primers forward and reverse primers (Table S2); $10 \mu \mathrm{l}$ of molecular graded DDW (Sigma, Israel) and; $2 \mu \mathrm{l}$ of (2-100 $\mathrm{ng} / \mu \mathrm{l})$ DNA template. PCR-I reactions were performed in Biometra thermal cycler (Biometra, TGradient 48) as the following: initial denaturation $95^{\circ} \mathrm{C}$ for $2 \mathrm{~min}$, followed by 35 cycles of $98{ }^{\circ} \mathrm{C}$ for $10 \mathrm{sec}, 61^{\circ} \mathrm{C}$ for $15 \mathrm{sec}$, and $72{ }^{\circ} \mathrm{C}$ for $7 \mathrm{sec}$. Ending the PCR-I routine was a final extension for $72^{\circ} \mathrm{C}$ for $1 \mathrm{~min}$. Upon completion of PCR-I, an electrophoresis gel was run to verify all the samples worked successfully. Following successful and verified amplification, triplicate samples were pooled together and were cleaned using Agencourt ${ }^{\circledR}$ AMPure XP (Beckman Coulter, Inc, Indianapolis, USA) bead solution based on manufacturer's protocol.

\subsubsection{Library Preparation and Illumina Miseq sequencing}

Library preparation was performed using a second PCR (PCR-II) to connect the illumina linker, adapter and unique 8 base pair barcode for each sample [59]. The PCR-II reactions were prepared by mixing $21 \mu \mathrm{l}$ of KAPA HiFi HotStart ReadyMix (biosystems, Israel), $2 \mu$ l of mixed primers with illumina adapter (Table S3), $12.6 \mu$ l of RNase free water (Sigma, Israel), $4 \mu$ l of each sample from the first PCR product with $2 \mu$ l 
of barcoded reverse primer, and placed in Biometra thermal cycler (Biometra, TGradient 48) as the following: initial denaturation $98^{\circ} \mathrm{C}$ for $2 \mathrm{~min}$, and then 8 cycles of $98^{\circ} \mathrm{C}$ for $10 \mathrm{sec} ; 64^{\circ} \mathrm{C}$ for $15 \mathrm{sec} ; 72$ ${ }^{\circ} \mathrm{C}$ for $25 \mathrm{sec}$; and final extension of $72{ }^{\circ} \mathrm{C}$ for $5 \mathrm{~min}$. Then all PCR-ll products were pooled together and subjected to cleaning using Agencourt® AMPure XP (Beckman Coulter, Inc, Indianapolis, USA) bead solution based on manufacturer's protocol, where $50 \mu$ of pooled PCR-Il product were cleaned using 1:1 ratio with the bead solution for more conservative size exclusion of fragments less than $200 \mathrm{bp}$, and at the final step, $50 \mu \mathrm{l}$ of DDW with $10 \mathrm{mM}$ Tris [pH = 8.5] were added to each sample. This was followed by aliquoting $48 \mu \mathrm{l}$ of the supernatant to sterile PCR tubes and storing in $-80^{\circ} \mathrm{C}$, while an additional $15 \mu \mathrm{l}$ of the final product was sent to the Hebrew University (Jerusalem, Israel) and sequenced on full lane of 150 bp paired-end (to correct for sequencing error and enhance total read quality) reads using illumina Miseq platform.

\subsection{Sequence analysis and quality control}

A series of sequence quality control steps were applied before data analysis. These included the following steps: all samples were filtered for PhiX contamination using Bowtie2 [60]; incomplete and lowquality (phred Q threshold 33) sequences were removed by pairing the two reads using PEAR software [61]; ambiguous bases and miss-merged sequences were identified using the MOTHUR Software V.1.36.1 [62]. Following quality control, QIIME-1 software [63] was used. Sequences were aligned, checked for chimeric sequences and clustered to different OTUs (operational taxonomic unit) based on $97 \%$ sequence similarity, then the sequences were classified based on Greengenes database V13.8 [64], and an OTU table was generated. All sequences classified as $f \_m i t o c h o n d r i a, c \_C h l o r o p l a s t, ~ k \_$Archaea and $\mathrm{K} \_$Unclassified, were removed from the OTU table.

\subsubsection{OTU richness and diversity estimates}

For each sample, four diversity estimates were measured; (i) observed number of OTUs, (ii) Chao1 species' diversity estimate [65], (iii) Simpson diversity index [66], and (iv) Shannon bacterial communities' diversity [67]. All these diversity metrics were calculated in QIIME-1 software [68] using the parallel_alpha_diversity.py command on the rarefaction subsamples to 10,000 sequences using multiple_rarefactions.py command.

\subsubsection{Assessment of community composition}

From the obtained QIIME classified OTU table, each taxonomic group was allocated down to the genus level using summarize_taxa.py command in Qiime and relative abundance was set as the number of sequences affiliated with that taxonomic level divided by the total number of sequences. Relative 
abundances were plotted using R statistical software [69] where each phylum was assigned a distinguished colour and all genera under the same phylum, were assigned to different shades of the same colour.

\subsubsection{Statistical Analysis}

Using R statistical software [69] all samples were analyzed based on the previously generated OTU table. Using the VEGAN package [70] in R, non-parametric multidimensional scaling (NMDS) were used to produce ordination based on Bray-Curtis distance matrix using a total sum transformed matrix for the row OTU table [71]. Canonical correspondence analysis (CCA) was used to plot abiotic factors and to show how they explain variance in the microbial communities [72]. In addition, ANOSIM was used to assess statistical microbial community similarity between endophytic and epiphytic community composition among different acacia species; PERMANOVA was used to test the effect of canopy, epi- and endophytes across time using adonis 2 function in $\mathrm{R}$; and the relative abundance of different bacterial phyla were tested using ANOVA with post-hoc Tukey HSD test for group significance.

\section{Declarations}

Ethics approval and consent to participate

Not applicable

Consent to publish

All author approve the submission

Authors' information (optional)

Not applicable

Availability of data and material

All curated sequences were joined into a single fasta file and submitted to MG-RAST under project link (https://www.mg-rast.org/linkin.cgi?project=mgp92155). 
All codes for quaration steps, quality control and sequence analysis uploaded to GitHub repository, including the metadata files and made publicly available (https://github.com/ashrafashhab/Desert-plantmicrobiome).

Competing interests

All authors declare no conflict of interest

\section{Funding}

This research was supported by ICA funding agency, grant number: 03-16-06A

\section{Authors' contributions}

Dr. Ashraf Al Ashhab was involved in the project conceptualization, data curation, formal analysis, methodology, project administration, resources, visualization and MS writing. Dr. Shiri Meshner, Michael Brandwein and Dr. Gidon Winters were involved in funding acquisition, project conceptualization and project investigation. In addition, both Dr. Gidon Winters and Dr. Yael Bar-Lavan took an active part in MS and graphics revision and editing. Ms. Rivka Alexander-Shani and Hana Dimerets helped in laboratory and field work.

\section{Acknowledgments}

We thank the Israel Charitable Association (ICA) funding agency for its generous support of this research, awarded under grant number: 03-16-06A. We also thank Dr. Noam Shental from the Department of Computer Science at the Open University of Israel, for his generous support in preliminary data analysis, selection of 16 s Primes and his insight in experimental design. Special thanks to Ms. Tal Galker from Arava Studio for developing Figure 1 in the manuscript and we also thank Michelle Finzi for English language editing.

\section{References}

1. Stone BWG, Weingarten EA, Jackson CR. The role of the phyllosphere microbiome in plant health and function. In: Annual Plant Reviews online. Roberts JA, editor. Wiley; 2018. p. 533-56. doi:10.1002/9781119312994.apr0614.

2. Kembel SW, O'Connor TK, Arnold HK, Hubbell SP, Wright SJ, Green JL. Relationships between 
phyllosphere bacterial communities and plant functional traits in a neotropical forest. Proc Natl Acad Sci USA. 2014;111:13715-20. doi:10.1073/pnas.1216057111.

3. Martirosyan V, Steinberger Y. Microbial functional diversity in the phyllosphere and laimosphere of different desert plants. J Arid Environ. 2014;107:26-33. doi:10.1016/j.jaridenv.2014.04.002.

4. Saleem M, Meckes N, Pervaiz ZH, Traw MB. Microbial Interactions in the Phyllosphere Increase Plant Performance under Herbivore Biotic Stress. Front Microbiol. 2017;8:41. doi:10.3389/fmicb.2017.00041. 5. Whipps JM, Hand P, Pink D, Bending GD. Phyllosphere microbiology with special reference to diversity and plant genotype. J Appl Microbiol. 2008;105:1744-55. doi:10.1111/j.1365-2672.2008.03906.x.

6. Agler MT, Ruhe J, Kroll S, Morhenn C, Kim S-T, Weigel D, et al. Microbial hub taxa link host and abiotic factors to plant microbiome variation. PLoS Biol. 2016;14:e1002352. doi:10.1371/journal.pbio.1002352. 7. Redford AJ, Bowers RM, Knight R, Linhart Y, Fierer N. The ecology of the phyllosphere: geographic and phylogenetic variability in the distribution of bacteria on tree leaves. Environ Microbiol. 2010;12:2885-93. doi:10.1111/j.1462-2920.2010.02258.x.

8. Martirosyan V, Unc A, Miller G, Doniger T, Wachtel C, Steinberger Y. Desert Perennial Shrubs Shape the Microbial-Community Miscellany in Laimosphere and Phyllosphere Space. Microb Ecol. 2016;72:659-68. doi:10.1007/s00248-016-0822-9.

9. Qvit-Raz N, Jurkevitch E, Belkin S. Drop-size soda lakes: transient microbial habitats on a salt-secreting desert tree. Genetics. 2008;178:1615-22. doi:10.1534/genetics.107.082164.

10. Carvalho SD, Castillo JA. Influence of Light on Plant-Phyllosphere Interaction. Front Plant Sci. 2018;9:1482. doi:10.3389/fpls.2018.01482.

11. Finkel OM, Burch AY, Elad T, Huse SM, Lindow SE, Post AF, et al. Distance-decay relationships partially determine diversity patterns of phyllosphere bacteria on Tamarix trees across the Sonoran Desert [corrected]. Appl Environ Microbiol. 2012;78:6187-93. doi:10.1128/AEM.00888-12.

12. Lambais MR, Barrera SE, Santos EC, Crowley DE, Jumpponen A. Phyllosphere Metaproteomes of Trees from the Brazilian Atlantic Forest Show High Levels of Functional Redundancy. Microb Ecol. 2017;73:123-34. doi:10.1007/s00248-016-0878-6.

13. Mwajita MR, Murage H, Tani A, Kahangi EM. Evaluation of rhizosphere, rhizoplane and phyllosphere bacteria and fungi isolated from rice in Kenya for plant growth promoters. Springerplus. 2013;2:606. doi:10.1186/2193-1801-2-606.

14. Batool F, Rehman Y, Hasnain S. Phylloplane associated plant bacteria of commercially superior wheat varieties exhibit superior plant growth promoting abilities. Front Life Sci. 2016;9:313-22.

doi:10.1080/21553769.2016.1256842.

15. Scavino AF, Pedraza RO. The Role of Siderophores in Plant Growth-Promoting Bacteria. In: Bacteria in agrobiology: crop productivity. Maheshwari DK, Saraf M, Aeron A, editors. Berlin, Heidelberg: Springer Berlin Heidelberg; 2013. p. 265-85. doi:10.1007/978-3-642-37241-4_11.

16. Fu S-F, Sun P-F, Lu H-Y, Wei J-Y, Xiao H-S, Fang W-T, et al. Plant growth-promoting traits of yeasts isolated from the phyllosphere and rhizosphere of Drosera spatulata Lab. Fungal Biol. 2016;120:433-48. doi:10.1016/j.funbio.2015.12.006.

17. Li S-B, Fang M, Zhou R-C, Huang J. Characterization and evaluation of the endophyte Bacillus B014 as a potential biocontrol agent for the control of Xanthomonas axonopodis pv. dieffenbachiae - Induced 
blight of Anthurium. Biological Control. 2012;63:9-16. doi:10.1016/j.biocontrol.2012.06.002.

18. Kefi A, Ben Slimene I, Karkouch I, Rihouey C, Azaeiz S, Bejaoui M, et al. Characterization of endophytic Bacillus strains from tomato plants (Lycopersicon esculentum) displaying antifungal activity against Botrytis cinerea Pers. World J Microbiol Biotechnol. 2015;31:1967-76. doi:10.1007/s11274-015-1943-x.

19. Copeland JK, Yuan L, Layeghifard M, Wang PW, Guttman DS. Seasonal community succession of the phyllosphere microbiome. Mol Plant Microbe Interact. 2015;28:274-85. doi:10.1094/MPMI-10-14-0331$\mathrm{Fl}$.

20. Redford AJ, Fierer N. Bacterial succession on the leaf surface: a novel system for studying successional dynamics. Microb Ecol. 2009;58:189-98. doi:10.1007/s00248-009-9495-y.

21. Leff JW, Del Tredici P, Friedman WE, Fierer N. Spatial structuring of bacterial communities within individual Ginkgo biloba trees. Environ Microbiol. 2015;17:2352-61. doi:10.1111/1462-2920.12695. 22. Rastogi G, Coaker GL, Leveau JHJ. New insights into the structure and function of phyllosphere microbiota through high-throughput molecular approaches. FEMS Microbiol Lett. 2013;348:1-10. doi:10.1111/1574-6968.12225.

23. Gomes T, Pereira JA, Benhadi J, Lino-Neto T, Baptista P. Endophytic and epiphytic phyllosphere fungal communities are shaped by different environmental factors in a mediterranean ecosystem. Microb Ecol. 2018;76:668-79. doi:10.1007/s00248-018-1161-9.

24. Stringer LC, Dyer JC, Reed MS, Dougill AJ, Twyman C, Mkwambisi D. Adaptations to climate change, drought and desertification: local insights to enhance policy in southern Africa. Environmental Science \& Policy. 2009;12:748-65. doi:10.1016/j.envsci.2009.04.002.

25. Vacher C, Hampe A, Porté AJ, Sauer U, Compant S, Morris CE. The Phyllosphere: Microbial Jungle at the Plant-Climate Interface. Annu Rev Ecol Evol Syst. 2016;47:1-24. doi:10.1146/annurev-ecolsys$121415-032238$.

26. Danin A. Desert vegetation of Israel and Sinai. Jerusalem: Cana Publishing House 148p-illus, col illus, maps. En Icones, Maps Geog. 1983;2.

27. Munzbergova Z, Ward D. Acacia trees as keystone species in Negev desert ecosystems. Journal of Vegetation Science. 2002;13:227-36. doi:10.1111/j.1654-1103.2002.tb02043.x.

28. Milton SJ. How useful is the keystone species concept, and can it be applied to Acacia erioloba in the Kalahari Desert?. Z Okologie Naturschutz. 1995;4:147-56.

29. Ward D, Rohner C. Anthropogenic causes of high mortality and low recruitment in three Acacia tree taxa in the Negev desert, Israel. Biodiversity and Conservation. 1997;6:877-93.

30. Rodger YS, Greenbaum G, Silver M, Bar-David S, Winters G. Detecting hierarchical levels of connectivity in a population of Acacia tortilis at the northern edge of the species' global distribution: Combining classical population genetics and network analyses. PLoS ONE. 2018;13:e0194901. doi:10.1371/journal.pone.0194901.

31. Winters G, Otieno D, Cohen S, Bogner C, Ragowloski G, Paudel I, et al. Tree growth and water-use in hyper-arid Acacia occurs during the hottest and driest season. Oecologia. 2018;188:695-705. doi:10.1007/s00442-018-4250-z.

32. ter Braak CJF. Canonical correspondence analysis: A new eigenvector technique for multivariate direct gradient analysis. Ecology. 1986;67:1167-79. doi:10.2307/1938672. 
33. Zhang B, Wu X, Tai X, Sun L, Wu M, Zhang W, et al. Variation in actinobacterial community composition and potential function in different soil ecosystems belonging to the arid heihe river basin of northwest china. Front Microbiol. 2019;10:2209. doi:10.3389/fmicb.2019.02209.

34. Amin A, Ahmed I, Khalid N, Khan IU, Ali A, Dahlawi SM, et al. Insights on comparative bacterial diversity between different arid zones of Cholistan Desert, Pakistan. 3 Biotech. 2020;10:224. doi:10.1007/s13205-020-02204-6.

35. Pontonio E, Di Cagno R, Tarraf W, Filannino P, De Mastro G, Gobbetti M. Dynamic and Assembly of Epiphyte and Endophyte Lactic Acid Bacteria During the Life Cycle of Origanum vulgare L. Front Microbiol. 2018;9:1372. doi:10.3389/fmicb.2018.01372.

36. Bodenhausen N, Horton MW, Bergelson J. Bacterial communities associated with the leaves and the roots of Arabidopsis thaliana. PLoS ONE. 2013;8:e56329. doi:10.1371/journal.pone.0056329.

37. Thapa S, Prasanna R. Prospecting the characteristics and significance of the phyllosphere microbiome. Ann Microbiol. 2018;68:229-45. doi:10.1007/s13213-018-1331-5.

38. Arndt SK, Arampatsis C, Foetzki A, Li X, Zeng F, Zhang X. Contrasting patterns of leaf solute accumulation and salt adaptation in four phreatophytic desert plants in a hyperarid desert with saline groundwater. J Arid Environ. 2004;59:259-70. doi:10.1016/j.jaridenv.2004.01.017.

39. Chaudhry V, Runge P, Sengupta P, Doehlemann G, Parker JE, Kemen E. Topic: Shaping the leaf microbiota: plant-microbe-microbe interactions. J Exp Bot. 2020. doi:10.1093/jxb/eraa417.

40. Remus-Emsermann MNP, Schlechter RO. Phyllosphere microbiology: at the interface between microbial individuals and the plant host. New Phytol. 2018;218:1327-33. doi:10.1111/nph.15054. 41. Schlechter RO, Miebach M, Remus-Emsermann MNP. Driving factors of epiphytic bacterial communities: A review. J Advanc Res. 2019;19:57-65. doi:10.1016/j.jare.2019.03.003.

42. Terhonen E, Blumenstein K, Kovalchuk A, Asiegbu F. Forest tree microbiomes and associated fungal endophytes: functional roles and impact on forest health. Forests. 2019;10:42. doi:10.3390/f10010042. 43. Baldrian P. Forest microbiome: diversity, complexity and dynamics. FEMS Microbiol Rev. 2017;41:109-30. doi:10.1093/femsre/fuw040.

44. Bodenhausen N, Bortfeld-Miller M, Ackermann M, Vorholt JA. A synthetic community approach reveals plant genotypes affecting the phyllosphere microbiota. PLoS Genet. 2014;10:e1004283. doi:10.1371/journal.pgen.1004283.

45. Müller H, Berg C, Landa BB, Auerbach A, Moissl-Eichinger C, Berg G. Plant genotype-specific archaeal and bacterial endophytes but similar Bacillus antagonists colonize Mediterranean olive trees. Front Microbiol. 2015;6:138. doi:10.3389/fmicb.2015.00138.

46. Hardoim PR, van Overbeek LS, Berg G, Pirttilä AM, Compant S, Campisano A, et al. The Hidden World within Plants: Ecological and Evolutionary Considerations for Defining Functioning of Microbial Endophytes. Microbiol Mol Biol Rev. 2015;79:293-320. doi:10.1128/MMBR.00050-14.

47. Liu H, Brettell LE, Singh B. Linking the phyllosphere microbiome to plant health. Trends Plant Sci. 2020;25:841-4. doi:10.1016/j.tplants.2020.06.003.

48. Given C, Häikiö E, Kumar M, Nissinen R. Tissue-Specific Dynamics in the Endophytic Bacterial Communities in Arctic Pioneer Plant Oxyria digyna. Front Plant Sci. 2020;11:561.

doi:10.3389/fpls.2020.00561.

Page 16/25 
49. Hussain MI, tsombou FM, El-Keblawy A. Surface canopy position determines the photosystem II photochemistry in invasive and native prosopis congeners at sharjah desert, UAE. Forests. 2020;11:740. doi:10.3390/f11070740.

50. Laforest-Lapointe I, Messier C, Kembel SW. Tree phyllosphere bacterial communities: exploring the magnitude of intra- and inter-individual variation among host species. PeerJ. 2016;4:e2367. doi:10.7717/peerj.2367.

51. Kim M, Singh D, Lai-Hoe A, Go R, Abdul Rahim R, Ainuddin AN, et al. Distinctive phyllosphere bacterial communities in tropical trees. Microb Ecol. 2012;63:674-81. doi:10.1007/s00248-011-9953-1.

52. Finkel OM, Delmont TO, Post AF, Belkin S. Metagenomic Signatures of Bacterial Adaptation to Life in the Phyllosphere of a Salt-Secreting Desert Tree. Appl Environ Microbiol. 2016;82:2854-61. doi:10.1128/AEM.00483-16.

53. Finkel OM, Burch AY, Lindow SE, Post AF, Belkin S. Geographical location determines the population structure in phyllosphere microbial communities of a salt-excreting desert tree. Appl Environ Microbiol. 2011;77:7647-55. doi:10.1128/AEM.05565-11.

54. Ginat H, Shlomi Y, Baterseh S, Vogel J. Reduction in Precipitation Levels in the Arava Valley (Southern Israel and Jordan), 1949-2009. Journal of Dead-Sea and Arava Research. 2011.

55. Ward D. The effects of apical meristem damage on growth and defences of two Acacia species in the Negev Desert. Evolutionary Ecology Research. 2010.

56. Sher AA, Wiegand K, Ward D. Do Acacia and Tamarix trees compete for water in the Negev desert? J Arid Environ. 2010;74:338-43. doi:10.1016/j.jaridenv.2009.09.007.

57. Winters G, Ryvkin I, Rudkov T, Moreno Z, Furman A. Mapping underground layers in the super arid Gidron Wadi using electrical resistivity tomography (ERT). J Arid Environ. 2015;121:79-83. doi:10.1016/j.jaridenv.2015.05.008.

58. Shrestha MK, Stock WD, Ward D, Golan-Goldhirsh A. Water status of isolated Negev desert populations of Acacia raddiana with different mortality levels. Springer Science and Business Media LLC. 2003. doi:10.1023/a:1024431124954.

59. Fuks G, Elgart M, Amir A, Zeisel A, Turnbaugh PJ, Soen Y, et al. Combining 16S rRNA gene variable regions enables high-resolution microbial community profiling. Microbiome. 2018;6:17. doi:10.1186/s40168-017-0396-x.

60. Langmead B, Salzberg SL. Fast gapped-read alignment with Bowtie 2. Nat Methods. 2012;9:357-9. doi:10.1038/nmeth.1923.

61. Zhang J, Kobert K, Flouri T, Stamatakis A. PEAR: a fast and accurate Illumina Paired-End reAd mergeR. Bioinformatics. 2014;30:614-20. doi:10.1093/bioinformatics/btt593.

62. Schloss PD, Westcott SL, Ryabin T, Hall JR, Hartmann M, Hollister EB, et al. Introducing mothur: opensource, platform-independent, community-supported software for describing and comparing microbial communities. Appl Environ Microbiol. 2009;75:7537-41. doi:10.1128/AEM.01541-09.

63. Caporaso JG, Kuczynski J, Stombaugh J, Bittinger K, Bushman FD, Costello EK, et al. QIIME allows analysis of high-throughput community sequencing data. Nat Methods. 2010;7:335-6. doi:10.1038/nmeth.f.303.

64. DeSantis TZ, Hugenholtz P, Larsen N, Rojas M, Brodie EL, Keller K, et al. Greengenes, a chimera- 
checked 16S rRNA gene database and workbench compatible with ARB. Appl Environ Microbiol. 2006;72:5069-72. doi:10.1128/AEM.03006-05.

65. Hill TCJ, Walsh KA, Harris JA, Moffett BF. Using ecological diversity measures with bacterial communities. FEMS Microbiol Ecol. 2003;43:1-11. doi:10.1111/j.1574-6941.2003.tb01040.x.

66. Keylock CJ. Simpson diversity and the Shannon-Wiener index as special cases of a generalized entropy. Oikos. 2005;109:203-7. doi:10.1111/j.0030-1299.2005.13735.x.

67. Haegeman B, Hamelin J, Moriarty J, Neal P, Dushoff J, Weitz JS. Robust estimation of microbial diversity in theory and in practice. ISME J. 2013;7:1092-101. doi:10.1038/ismej.2013.10.

68. Kuczynski J, Stombaugh J, Walters WA, González A, Caporaso JG, Knight R. Using QIIME to analyze 16S rRNA gene sequences from microbial communities. Curr Protoc Microbiol. 2012;Chapter 1:Unit 1E.5. doi:10.1002/9780471729259.mc01e05s27.

69. R Core Team. R: A language and environment for statistical computing. 2013.

70. Oksanen FJ, Friendly M, Kindt R, Legendre P, McGlinn D, Minchin PR, et al. Vegan: community ecology package. R package version. 2018;2.

71. Sinclair L, Osman OA, Bertilsson S, Eiler A. Microbial community composition and diversity via $16 \mathrm{~S}$ rRNA gene amplicons: evaluating the illumina platform. PLoS ONE. 2015;10:e0116955.

doi:10.1371/journal.pone.0116955.

72. Gonzalez I, Déjean S, Martin P, Baccini A. cca: anr package to extend canonical correlation analysis. J Stat Softw. 2008;23. doi:10.18637/jss.v023.i12.

\section{Tables}

Table 1 Average diversity estimates $( \pm S D)$ of microbial communities of $A$. raddiana and $A$. tortilis measured across the entire sampling months for the epiphyte at north $(\mathrm{N})$ and center $(\mathrm{C})$ canopy sides and for both epi- and endophytes at south (S) canopy side. 


\begin{tabular}{|llllll|}
\hline Species & Canopy & $\begin{array}{l}\text { Observed number } \\
\text { of OTUs }\end{array}$ & Chao1 & $\begin{array}{l}\text { Simpson } \\
\text { diversity index }\end{array}$ & $\begin{array}{l}\text { Shannon- } \\
\text { Wienerdiversity } \\
\text { index }\end{array}$ \\
\hline \multirow{2}{*}{$\begin{array}{l}\text { A. } \\
\text { raddiana }\end{array}$} & N-epiphyte & $460.5 \pm 273.1$ & $716.8 \pm 367.6$ & $0.8 \pm 0.2$ & $3.5 \pm 1.1$ \\
\cline { 2 - 6 } & C-epiphyte & $387.3 \pm 228.1$ & $614.7 \pm 327.1$ & $0.9 \pm 0.1$ & $3.4 \pm 1.0$ \\
\cline { 2 - 6 } A. tortilis & S-epiphyte & $445.5 \pm 210.2$ & $680.9 \pm 300.3$ & $0.9 \pm 0.1$ & $3.6 \pm 0.8$ \\
\cline { 2 - 6 } & $\begin{array}{l}\text { S- } \\
\text { endophytes }\end{array}$ & $236.5 \pm 42.6$ & $368.5 \pm 89.4$ & $0.6 \pm 0.2$ & $1.9 \pm 0.7$ \\
\cline { 2 - 6 } & C-epiphyte & $519.7 \pm 254.4$ & $811.0 \pm 373.2$ & $0.8 \pm 0.2$ & $3.3 \pm 1.0$ \\
\cline { 2 - 6 } & S-epiphyte & $512.5 \pm 262.7$ & $754.2 \pm 349.6$ & $0.9 \pm 0.1$ & $3.4 \pm 0.7$ \\
\cline { 2 - 6 } & $\begin{array}{l}\text { S- } \\
\text { endophytes }\end{array}$ & $148.3 \pm 46.9$ & $242.7 \pm 80.8$ & $0.6 \pm 0.2$ & $1.8 \pm 0.6$ \\
\hline
\end{tabular}

Table 2 PERMANOVA analysis showing statistical significance of epiphytic microbial communities across canopy sides and sampling month.

\begin{tabular}{lccccc} 
& Df & \multicolumn{2}{c}{ SumOfSqs } & R2 & \multicolumn{2}{c}{$\operatorname{Pr}(>F)$} \\
Canopy & 2 & 0.3599802 & 0.01505864 & 1.035904 & 0.350 \\
Month & 8 & 6.1159271 & 0.25584059 & 4.399903 & 0.001 \\
Canopy:Month & 16 & 3.5291777 & 0.14763206 & 1.269476 & 0.004 \\
Residuals & 80 & 13.9001407 & 0.58146871 & & \\
Total & 106 & 23.9052257 & 1.00000000 & &
\end{tabular}

Table 3 PERMANOVA analysis showing statistical significance of epiphytic and endophytic microbial communities across sampling month.

\begin{tabular}{lcrrrr} 
& Df & SumOfSqs & R2 & \multicolumn{2}{c}{$\operatorname{Pr}(>F)$} \\
Epi_Endo & 1 & 4.477580 & 0.2555588 & 25.208023 & 0.001 \\
Month & 8 & 2.270971 & 0.1296161 & 1.598148 & 0.017 \\
Epi_Endo:Month & 8 & 2.246182 & 0.1282013 & 1.580703 & 0.015 \\
Residuals & 48 & 8.526009 & 0.4866238 & &
\end{tabular}




\section{Figures}

(A)

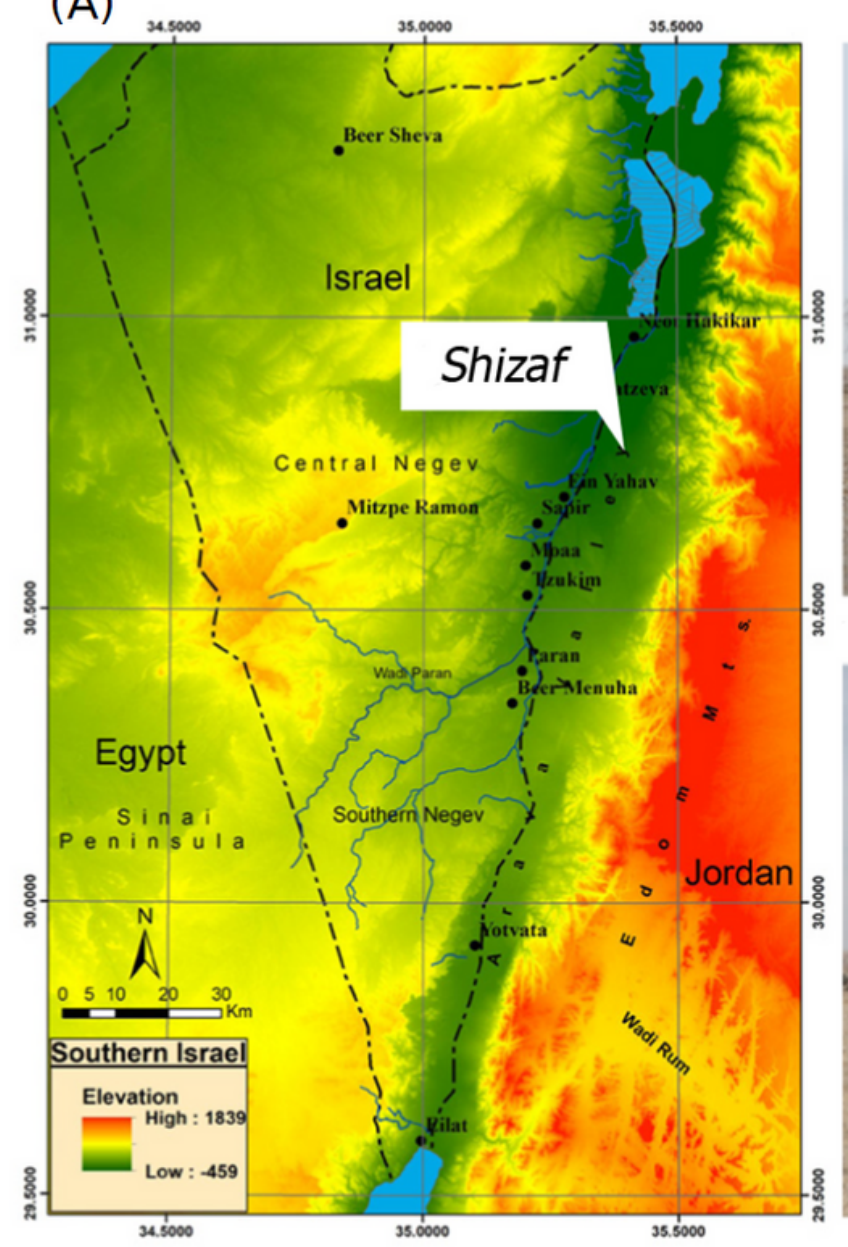

(B)

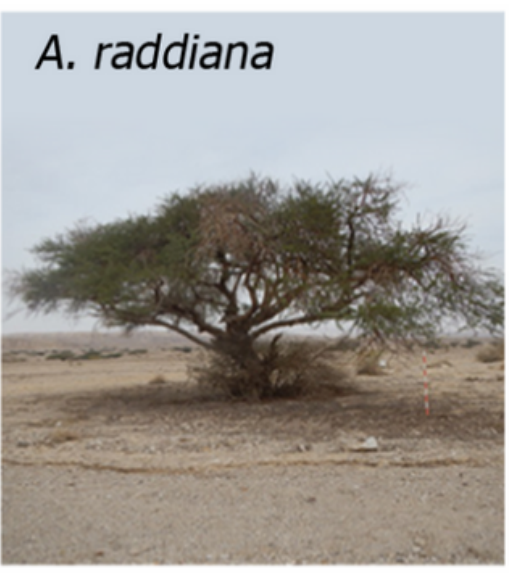

\section{A. tortilis}

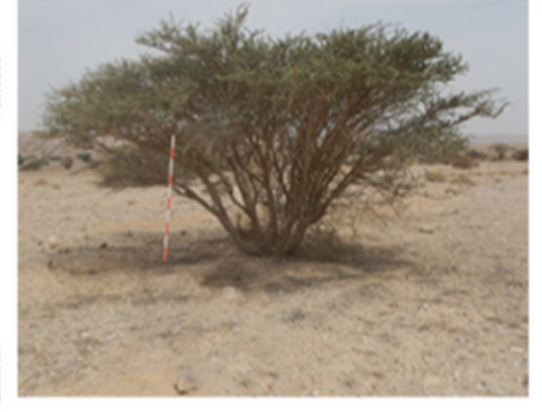

(C)

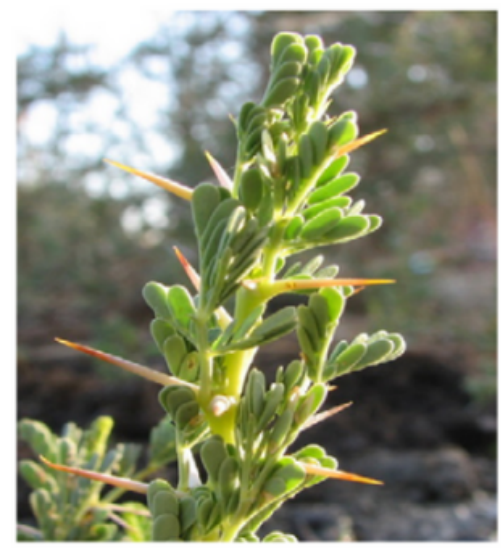

(D)

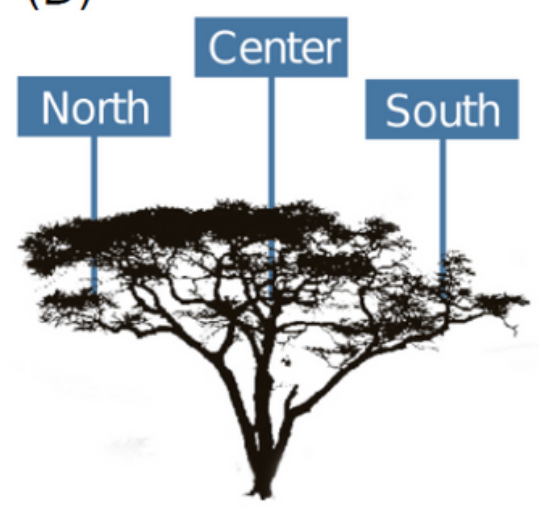

\section{Figure 1}

Southern Israel topography map showing the study site, Wadi Shizaf (A), and acacia trees (A. raddiana and A. tortilis; B) sampled monthly during 2015. In each month, leaf samples (example of leaves collected shown in C) were collected from the north, center and south sides of the canopies (D). 
(A)

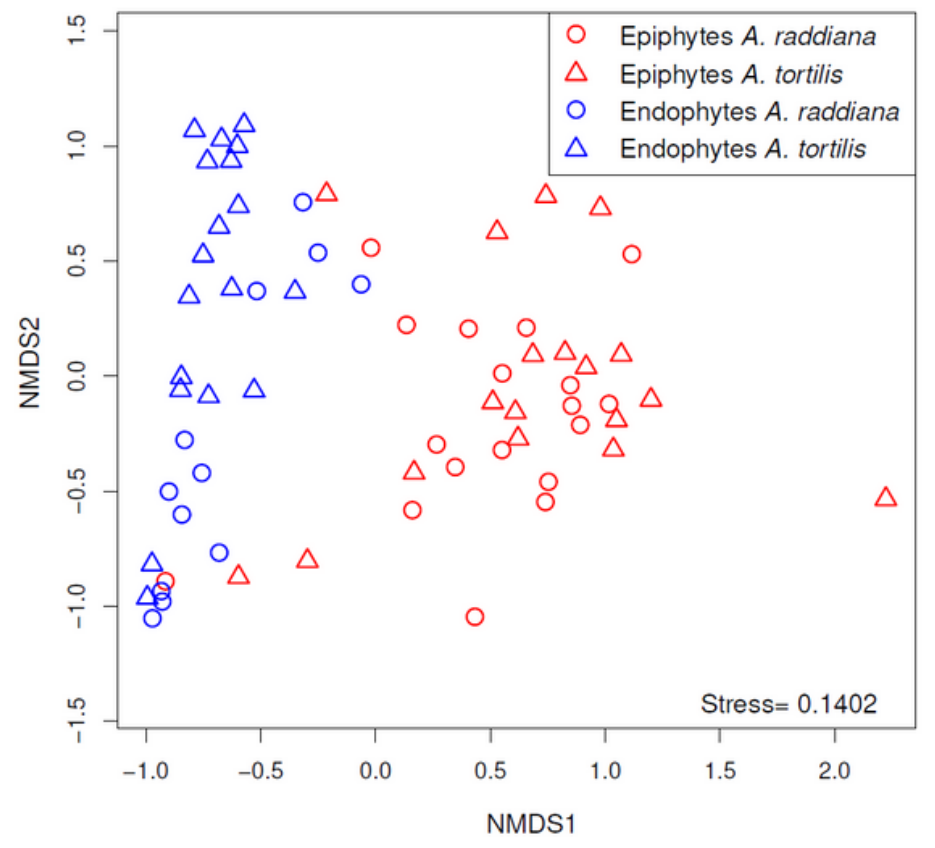

(B)

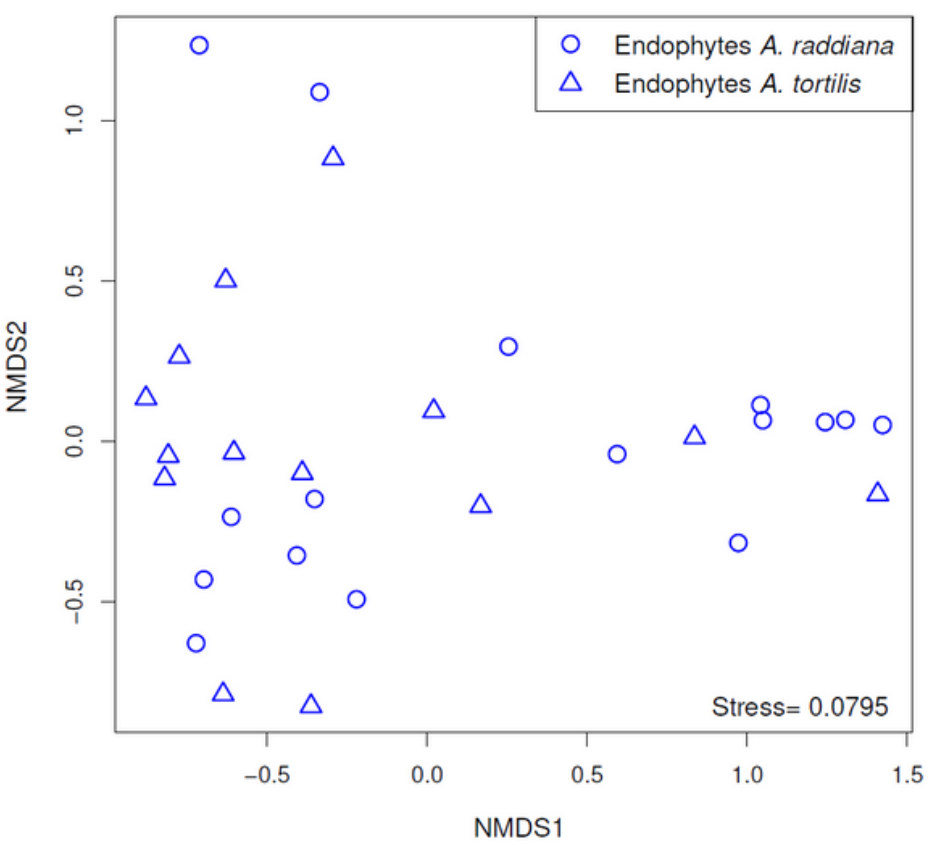

Figure 2

NMDS illustrating the phyllosphere bacterial community; separate clusters of bacterial communities are evident: (A) the epiphytic (red) and the endophytic (blue) bacterial communities from leaves sampled from south side canopy areas; and (B) unique clusters of endophytic bacterial communities observed in A. raddiana (blue) and $A$. tortilis leaves. 


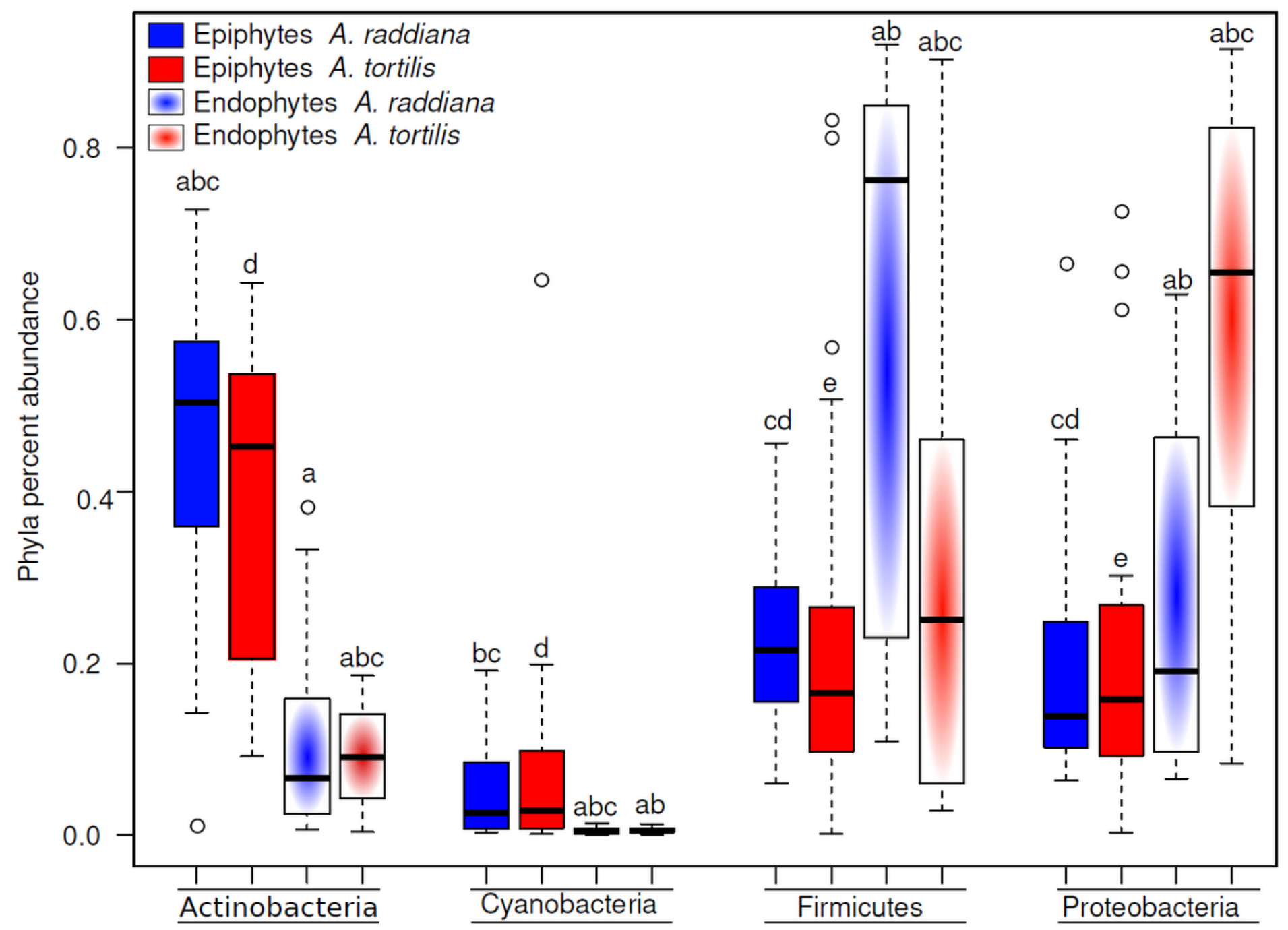

Figure 3

Box plot illustrating the percent abundance of epi- and endophyte major bacterial phyla. 
(A)

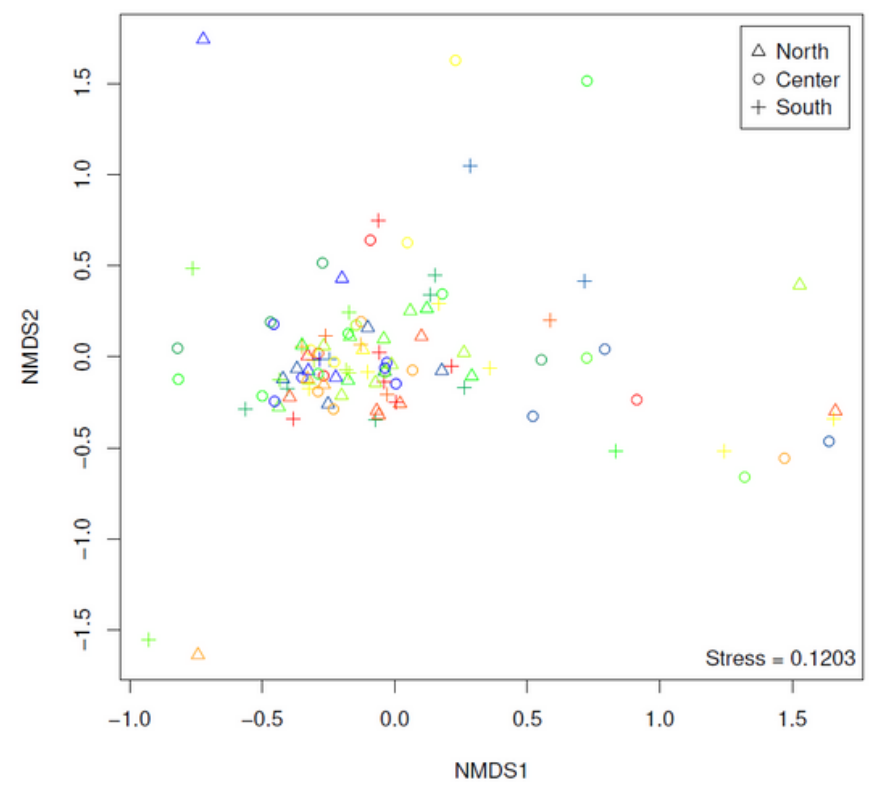

(B)

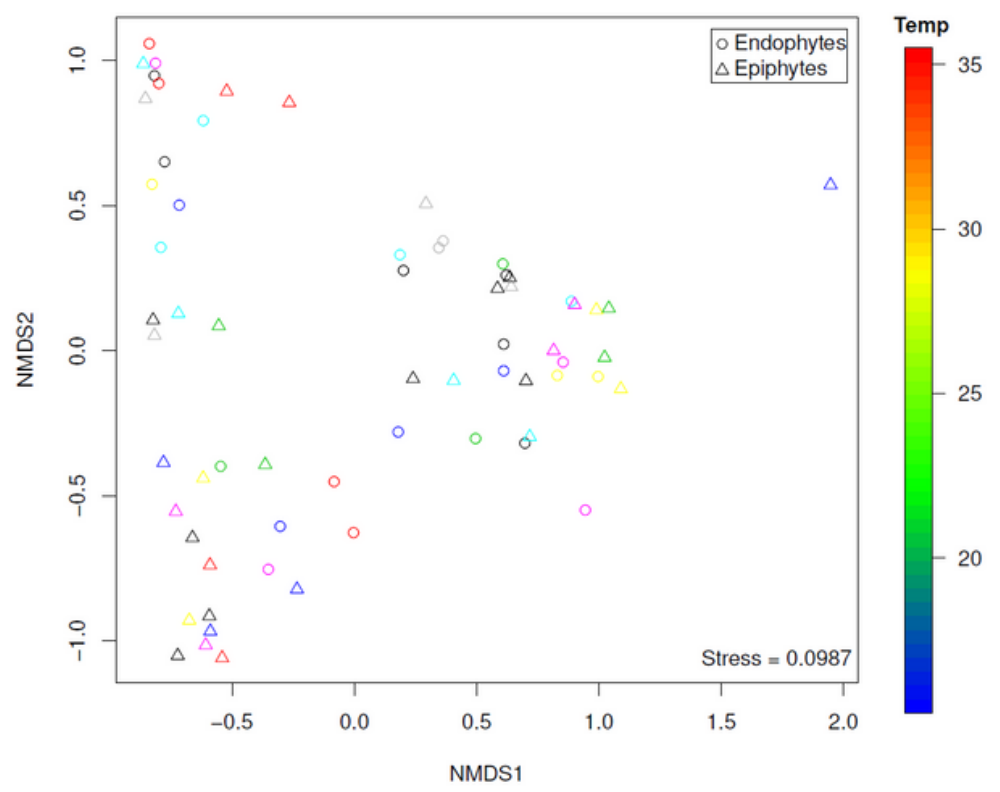

\section{Figure 4}

NMDS illustrating the epiphytic phyllosphere bacterial communities at different canopy sides (north, center and south) (A), and both epiphytic and endophytic at the south canopy side (B). Color gradient (blue to red) represents temperatures recorded every month.

(A)

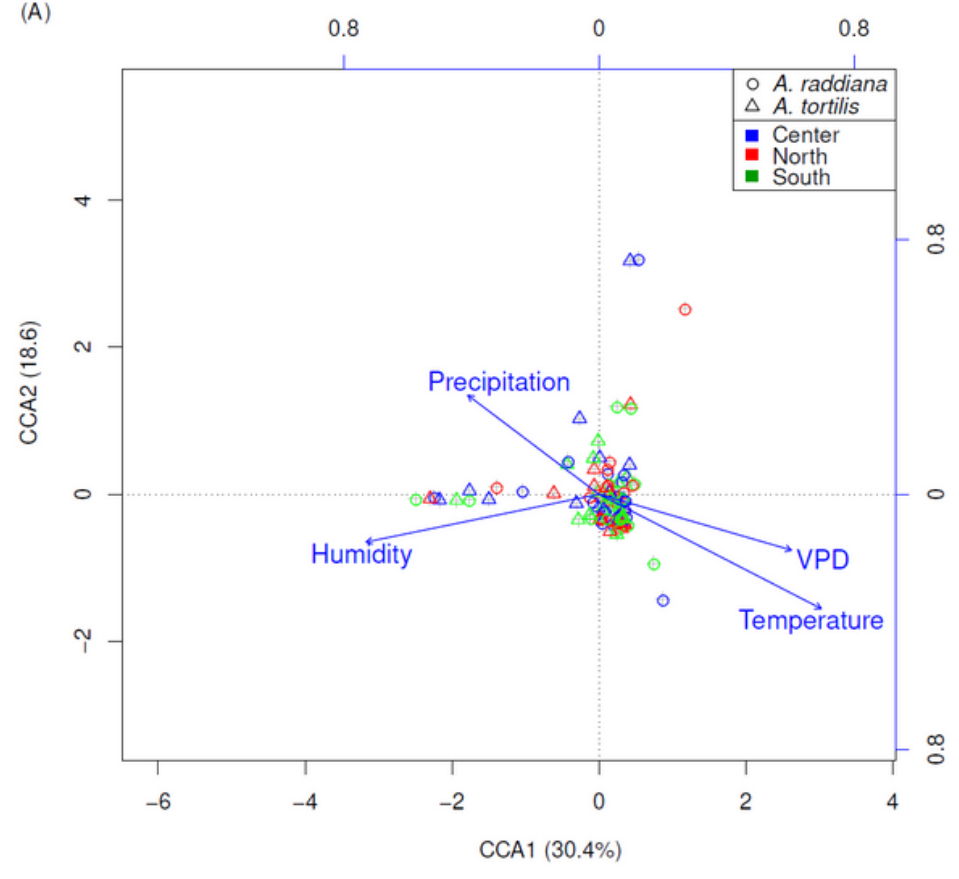

(B) 0.

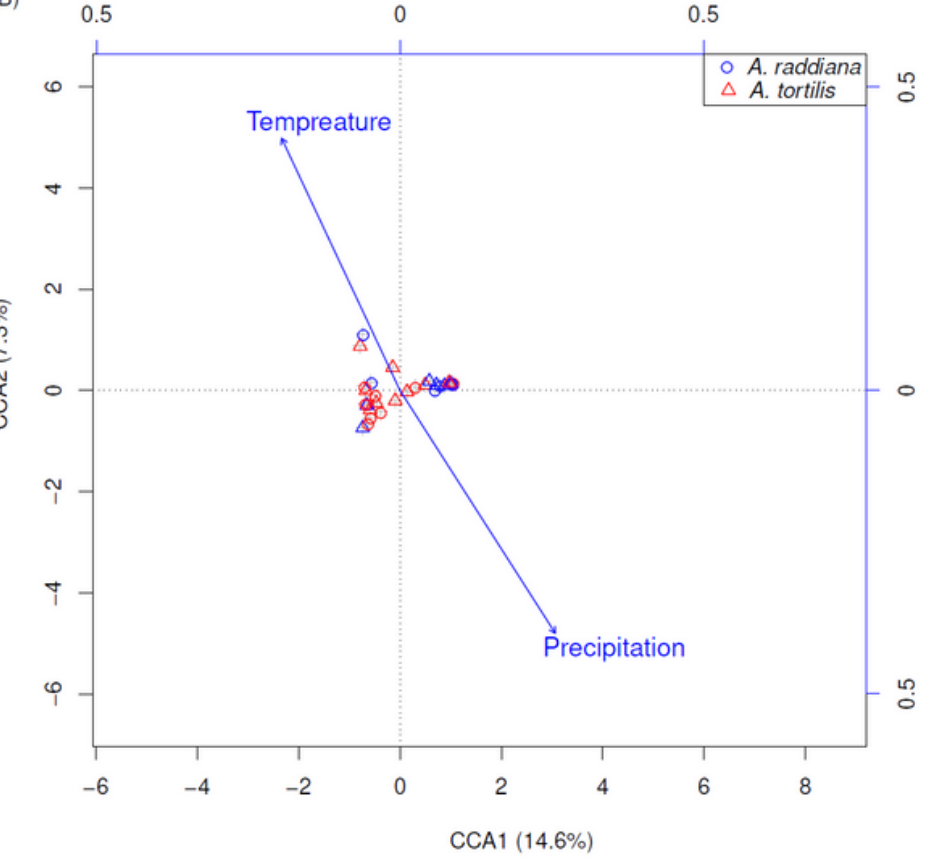

\section{Figure 5}

CCA ordination illustrating (A) epiphytic bacterial community at north (red), south (green) and center (blue) canopy sides and (B) endophytic bacterial communities, for A. raddiana (blue-circles) and A. tortilis (red-triangles) with significant abiotic factors affecting the bacterial communities. 


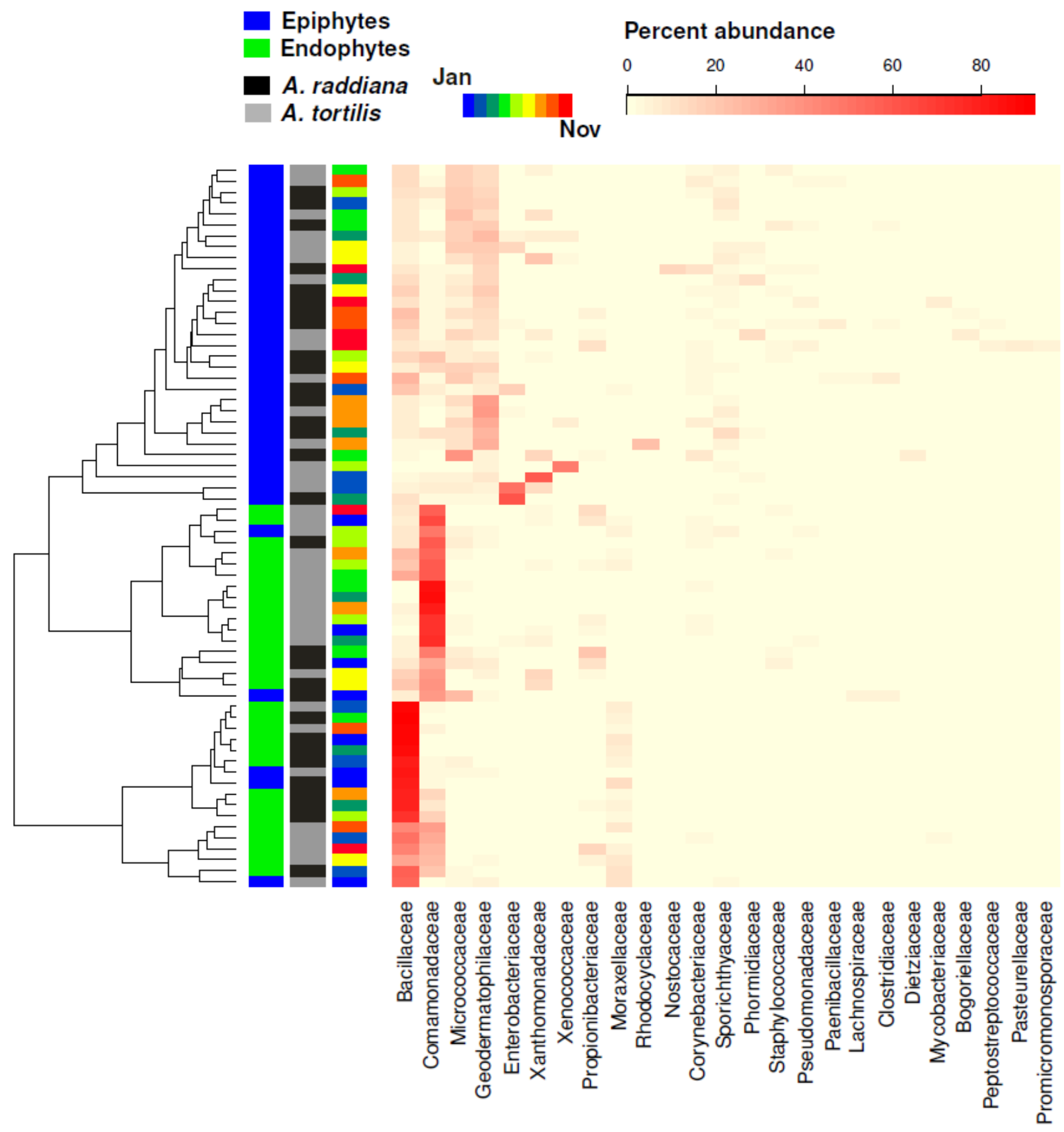

Figure 6

Heatmap showing the abundance of bacterial family abundances (x-axis) for each of the sampled epiphytic and endophytic bacterial communities at the south canopy side at different sampling months (January-November).

\section{Supplementary Files}


This is a list of supplementary files associated with this preprint. Click to download.

- TableS1.docx

- Tables2.docx

- TableS3.docx

- Tables4.docx

- FigureS1.pdf

- Figures2.pdf

- FigureS3.pdf 